\title{
Analysis of the Effect of Investment, Labor Force and Infrastructure on Economic Growth in North Sumatra Province
}

\author{
Taufik Akbar ${ }^{1}$, Tarmizi $^{1}$, Syafii ${ }^{1}$ \\ ${ }^{1}$ Department of Economics, Faculty of Economics and Business at Universitas Sumatera Utara, Indonesia
}

Corresponding Author: Taufik Akbar

\begin{abstract}
A significant amount of value investment can absorb much labor and increase public consumption to become productive. Infrastructure development is believed to facilitate the mobility of goods and people from one area to another to accelerate and streamline the economic process. The purposes of this study were to analyze the effects of the value realization of Domestic Investment, the value realization of Foreign Investment, the labor force, and infrastructure partially and simultaneously on the economic growth of North Sumatra Province. The data in this study is secondary data sources on the Statistics Indonesia (BPS) report of Province Sumatra Utara, particularly the data from 1990-2019. The data examined included Gross Domestic Regional Product, Value Realization of Domestic Investment, Foreign Investment, Labour Force, and road infrastructure. The data collection method used is the method of documentation. The model used is the Ordinary Least Square (OLS) model, which is analyzed by multiple regression. The results showed that, partially, there were positive and significant effects on the value realization of Domestic Investment, labor force, and infrastructure. Meanwhile, Foreign Investment showed a positive effect but not significant. Simultaneously, the realization of Domestic Investment, the realization of Foreign Investment, the labor force, and infrastructure were positive and significant on the economic growth of North Sumatra Province at the level of $\alpha=5 \%$.
\end{abstract}

Keywords: value realization of domestic investment, foreign investment, labor force, infrastructure.

\section{INTRODUCTION}

Economic growth is one of the essential indicators to analyze the economic development of a country or region. Economic growth is a process of increasing production capacity in an economy continuously or continuously over time, resulting in a higher level of national income and output (Todaro and Smith, 2004). According to Neo-Classical Economic Growth Theory, regional economic growth is measured by the growth of Gross Regional Domestic Product (GRDP), which depends on production factors, namely capital, labor, and technology (Sukirno, 2000). Thus, the economic growth of a country or region is expected to increase from year to year to become prosperous. North Sumatra Province is one of the provinces on Sumatra Island, which consists of 25 regencies and eight cities with a population of $14,562,549$ people in 2019. The economic growth of North Sumatra Province in 1990-2019 is shown in table 1 .

In table 1 , it can be seen that the economic growth of North Sumatra Province in 1991-1993 was around 7\%. In 1994-1996 there was an increase of about $9 \%$. The occurrence of the monetary crisis in 1998 had a negative impact on the economic growth of North Sumatra 
Province by around $-10.7 \%$. In 1999 economic growth recovered with an increase of about $2.53 \%$. Since 2000-2005 there has been an average positive economic growth of around 4\%-5\%. From 2006-2013 it fluctuated around 6\%, and in 2015-2019 there was a decrease of around 5\%. This decline indicates a decline in economic development in North Sumatra.

Table 1. Economic Growth Rate of North Sumatra Province 1990 - 2019

\begin{tabular}{|l|l|l|l|}
\hline Year & $\begin{array}{l}\text { GRDP's 2000 on } \\
\text { Constant Price } \\
\text { (Billion Rupiahs) }\end{array}$ & $\begin{array}{l}\text { GRDP's 2010 on } \\
\text { Constant Price } \\
\text { (Billion Rupiahs) }\end{array}$ & $\begin{array}{l}\text { Economic } \\
\text { Growth } \\
\text { (\%) }\end{array}$ \\
\hline 1990 & $5.934,56$ & $117.458,66$ & - \\
\hline 1991 & $6.364,63$ & $125.980,96$ & 7,25 \\
\hline 1992 & $6.832,67$ & $135.262,77$ & 7,36 \\
\hline 1993 & $58.215,45$ & $145.316,54$ & 7,43 \\
\hline 1994 & $61.942,02$ & $159.231,44$ & 9,57 \\
\hline 1995 & $65.810,87$ & $174.595,06$ & 9,64 \\
\hline 1996 & $71.582,94$ & $190.433,61$ & 9,07 \\
\hline 1997 & $74.988,17$ & $201.197,31$ & 5,65 \\
\hline 1998 & $67.411,22$ & $179.469,77$ & $-10,7$ \\
\hline 1999 & $65.968,01$ & $184.015,44$ & 2,53 \\
\hline 2000 & $69.154,11$ & $192.858,13$ & 4,80 \\
\hline 2001 & $71.908,35$ & $200.539,23$ & 3,98 \\
\hline 2002 & $75.189,14$ & $209.688,72$ & 4,56 \\
\hline 2003 & $78.805,60$ & $219.774,39$ & 4,80 \\
\hline 2004 & $83.328,95$ & $232.389,16$ & 5,73 \\
\hline 2005 & $87.897,79$ & $245.130,82$ & 5,48 \\
\hline 2006 & $93.347,40$ & $260.328,78$ & 6,19 \\
\hline 2007 & $99.792,27$ & $278.302,34$ & 6,90 \\
\hline 2008 & $106.172,36$ & $296.095,24$ & 6,39 \\
\hline 2009 & $111.559,22$ & $311.118,21$ & 5,07 \\
\hline 2010 & $118.718,90$ & $331.085,24$ & 6,41 \\
\hline 2011 & $126.587,62$ & $353.147,59$ & 6,66 \\
\hline 2012 & - & $375.924,14$ & 6,44 \\
\hline 2013 & - & $398.727,14$ & 6,06 \\
\hline 2014 & - & $419.573,31$ & 5,22 \\
\hline 2015 & - & $440.955,85$ & 5,09 \\
\hline 2016 & - & $463.775,46$ & 5,17 \\
\hline 2017 & - & $487.531,23$ & 5,12 \\
\hline 2018 & - & $512.762,63$ & 5,17 \\
\hline 2019 & - & $539.513,85$ & 5,21 \\
\hline & Source: BPS North Sumatra Province 2020 \\
\hline
\end{tabular}

This study, using GRDP based on constant prices in 2010 so that the calculation is more accurate with the current economic conditions. The data available at BPS is based on the 2010 GRDP's on constant price starting from 2010 onwards. So to get 2010 GRDP's on constant price data in 1990-2009 in this study by equating the 2010 GRDP's on constant price based on 2000 GRDP's on constant price.

Regional governments in regional development planning always set targets for economic growth and are directed at increasing community welfare and optimal distribution. Economic growth is an indication of the success of economic development, so to know the success of economic development of a region can be seen from the increase in the region's economic growth.

Development can be interpreted as an effort to increase further the productivity of potential resources owned by a country, both natural resources, human resources, capital or capital, as well as resources in the form of technology, with the ultimate goal of improving people's living standards (Todaro, 2000). Two factors can affect economic growth, namely economic factors and non-economic factors. Economic factors that affect economic growth include natural resources, capital accumulation, organization, labor, and technological progress. The non-economic factors include sociocultural, political, and administrative factors.

Regional economic development is when local governments and communities manage existing resources through a partnership pattern to create new jobs or job opportunities and stimulate economic growth. The development carried out must explore all the potential in each region to be processed to be helpful. These potentials consist of natural resources, human resources, cultural potentials, and other potentials that must be pursued and empowered optimally. Exploring all existing potential is very important to develop the capabilities and independence of each region. In addition, economic growth in a country becomes a measuring tool to see or analyze how far the level of economic development in that country is (Sukirno, 2000).

Capital accumulation is one part of economic growth. Capital accumulation or capital formation adds to the net physical capital stock in an economy to increase total output. Boediono (1999) investment is expenditure by the producer sector (private) to purchase goods and services to increase the stock used or factory expansion. 
Dornbusch, Fischer, and Startz (2004) argue that investment is the demand for goods and services to create or increase production capacity or income in the future. According to its usefulness, investment is a form of capital accumulation in economic growth. One of the development targets in all regions is to increase the rate of economic growth. The high economic growth is expected to have an even greater trickledown effect (Arsyad, 1999).

Through direct investment is one of the accumulations of capital to the physical capital stock, such as procurement of new factories, machinery, equipment, and raw materials, or by investing in supporting facilities such as investment in economic and social infrastructure (road construction, electricity, clean water, communication facilities, and others). The amount of domestic investment (DI) and foreign investment (FI) is an investment that is expected to absorb many workers, reduce unemployment, and have an impact on people's welfare.

According to Law no. 25 of 2007 , domestic investment is an activity to invest in conducting business in the territory of the Republic of Indonesia carried out by domestic investment and using domestic capital. The benefits of DI are as follows:

a. Able to save foreign exchange

b. Reducing dependence on foreign products

c. Encouraging the advancement of domestic industry through forwarding linkages and backward linkages.

d. Contribute to efforts to absorb labor.

While the factors that affect DI are:

a. Potential and characteristics of area

b. Community culture

c. Proportionate use of the regional economic era

d. Regional and national political maps

e. Accuracy of local governments in determining local policies and regional regulations that creates a conducive climate for business and investment.

Domestic investment (DI), is considered to encourage the economy of a developing country well. If the investment that occurs in the country has increased, it will increase economic growth (Jufrida, 2016).

The investment currently being increased by developing countries is an investment in the form of FI. According to the law of the Republic of Indonesia No. 25 of 2007 concerning Investment, foreign investment (FI) is an investment activity to conduct business in the territory of the Republic of Indonesia which foreign investors carry out, both those who use foreign capital wholly or in joint ventures with domestic investors. According to Salim and Budi (2008), foreign investment transfers tangible and intangible capital from one country to another or a transfer of capital. The purpose of the capital transfer is used in the country to generate profits under the supervision of capital's owners, either in total or in part.

According to Arsyad (2010), the benefits of foreign investment for developing countries are as follows:

a. To create jobs.

b. The process of transferring technology and valuable skills.

c. Source of savings or foreign exchange.

The study of Ostry et al. (2010) stated that although the benefits received are quite large, the magnitude of foreign flows can be an action of investors to protect the value of their investments so that they are temporary and can affect interest rates. FI is likely to increase output in the short term and limit economic growth in the long term because it is sensitive to interest rates. There is a decrease in capital productivity in the long term (minimizing marginal productivity of capital).

According to Effendi and Soemantri (2003), the direction of capital flows from the North (developed countries) to the South (developing countries) in 1999, FI accounted for more than half of the capital flows to developing countries. The main reason is that FI is believed to have several positive impacts, including increased productivity, technology transfer, new 
methods and processes, managerial skills, technical prowess in the domestic market, training of workers, international production networks, and access to markets. Thus, FI investment is a foreign investment that is expected to encourage the growth of the economic sector, which in turn will lead to an increase in GRDP.

Table 2. Realization of the value of DI and FI in North Sumatra Province 1990-2019

\begin{tabular}{|l|l|l|}
\hline Years & DI(Million Rupiah) & FI (Thousand US\$) \\
\hline 1990 & $250.409,60$ & $531.018,71$ \\
\hline 1991 & $227.071,03$ & $16.051,30$ \\
\hline 1992 & $118.243,37$ & $89.349,00$ \\
\hline 1993 & $139.124,37$ & $16.566,06$ \\
\hline 1994 & $552.053,56$ & $59.855,63$ \\
\hline 1995 & $316.447,01$ & $88.850,04$ \\
\hline 1996 & $243.353,07$ & $61.589,05$ \\
\hline 1997 & $444.803,50$ & $47.233,02$ \\
\hline 1998 & $37.239,13$ & $77.400,92$ \\
\hline 1999 & $89.038,93$ & $55.358,26$ \\
\hline 2000 & $80.120,65$ & $85.612,88$ \\
\hline 2001 & $225.305,89$ & $9.251,31$ \\
\hline 2002 & $11.788,37$ & $8.363,68$ \\
\hline 2003 & $311.500,00$ & $82.004,95$ \\
\hline 2004 & $1.364 .326,19$ & $199.946,60$ \\
\hline 2005 & $1.255 .717,99$ & $131.764,94$ \\
\hline 2006 & $102.676,59$ & $594.302,64$ \\
\hline 2007 & $1.612 .920,66$ & $931.772,86$ \\
\hline 2008 & $391.333,72$ & $104.820,87$ \\
\hline 2009 & $2.644 .965,26$ & $940.296,46$ \\
\hline 2010 & $1.703 .056,37$ & $321.829,19$ \\
\hline 2011 & $2.004 .055,78$ & $658.466,72$ \\
\hline 2012 & $2.970 .186,19$ & $645.300,00$ \\
\hline 2013 & $5.068 .881,40$ & $887.452,00$ \\
\hline 2014 & $5.231 .905,85$ & $550.835,10$ \\
\hline 2015 & $4.287 .417,30$ & $1.246 .096,20$ \\
\hline 2016 & $4.954 .829,29$ & $1.057 .989,14$ \\
\hline 2017 & $11.683 .639,20$ & $1.514 .942,90$ \\
\hline 2018 & $8.371 .820,30$ & $1.227 .609,40$ \\
\hline 2019 & $19.748 .995,10$ & $379.347,20$ \\
\hline & Source: BPS North Sumatra Province \\
\hline
\end{tabular}

The realization of the value of DI and FI in North Sumatra Province in 19902019 is presented in Table 2. The realization of the value of DI and FI in North Sumatra in 1990-2019 fluctuates from year to year. North Sumatra Province achieved the highest DI investment in 2019, valued at $19,748,995.10$ million rupiahs and the previous year at $8,371,820.30$ million rupiahs. The highest FI investment was in 2017, with an investment value of $1,514,942.90$ thousand US\$. Based on Table 2 , there was a decrease in the realized value of DI in 1998 with a value of 37,239.13 million rupiahs from the previous year in 1997 with a realized value of 444,803.50 million rupiahs. It happened simultaneously with the economic crisis at home and abroad. With the normalization of global economic conditions and the improvement in the investment climate in 2004, the realized value of DI in North Sumatra Province increased by $1,364,326$ million rupiahs.

The Central Statistics Agency (BPS) defines labor as all residents of productive age (aged 15 years or older) who can produce goods and services. These criteria become indicators used to make labor force planning policies at the regional and national levels. This indicator is also used to determine how many workers or potential working-age population can produce goods and services.

Todaro (2004) mentions that population growth and labor growth are traditionally regarded as the positive factors that spur economic growth. A larger number of workers means an increase in production level, while a larger population growth means a larger domestic market size. However, it is still questionable whether it is true that the rapid rate of population growth will have a positive or negative impact on its economic development. Furthermore, it is said that the positive or negative influence of population growth depends on the ability of the regional economic system to absorb and productively utilize the increase in labor.

The mainstream economy's view of the demand for labor is that the demand for production factors is considered a derived demand, a decline in the company's functions. Although the company's functions are quite varied, including maximizing profits, maximizing sales or behavior to provide satisfaction to consumers, profit maximization is often used as the basis for analysis in determining the use of labor (Makmum and Yasin, 2003).

This ability is influenced by the level and type of capital accumulation, the availability of inputs, and supporting factors such as managerial and administrative skills. In a simple economic growth model, the 
notion of labor is generally defined as a homogeneous labor force. According to Lewis in Todaro (2004), a homogeneous and unskilled labor force moves and switches from the traditional sector to the modern sector smoothly and in limited numbers. In such circumstances, the supply of labor contains a high elasticity. The increasing demand for labor from the traditional sector stems from the expansion of modern sector activities. The labor force in North Sumatra Province in 1990-2019 is presented in Table 3.

Table 3. Labor Force 15 Years Old and Over North Sumatra Province 1990-2019

\begin{tabular}{|c|c|c|c|c|}
\hline \multirow[t]{2}{*}{ Year } & \multicolumn{3}{|c|}{ Labor Force } & \multirow[t]{2}{*}{ Growth (\%) } \\
\hline & Working & Unemployed & Amount & \\
\hline 1990 & 3.820 .329 & 128.400 & 3.948 .729 & - \\
\hline 1991 & 3.914 .800 & 129.510 & 4.044 .310 & 2,42 \\
\hline 1992 & 4.099 .809 & 130.974 & 4.230 .783 & 4,61 \\
\hline 1993 & 4.193 .154 & 139.216 & 4.332 .370 & 2,40 \\
\hline 1994 & 4.318 .993 & 147.567 & 4.466 .560 & 3,09 \\
\hline 1995 & 4.493 .198 & 318.100 & 4.811 .298 & 7,71 \\
\hline 1996 & 4.575 .651 & 167.299 & 4.742 .950 & $-1,42$ \\
\hline 1997 & 4.642 .766 & 262.530 & 4.905 .296 & 3,42 \\
\hline 1998 & 4.855 .296 & 371.720 & 5.227 .016 & 6,55 \\
\hline 1999 & 4.735 .800 & 326.520 & 5.062 .320 & $-3,15$ \\
\hline 2000 & 4.947 .539 & 335.729 & 5.283 .268 & 4,36 \\
\hline 2001 & 4.977 .323 & 229.212 & 5.206 .535 & $-1,45$ \\
\hline 2002 & 4.928 .353 & 355.504 & 5.283 .857 & 1,48 \\
\hline 2003 & 4.835 .793 & 404.117 & 5.239 .910 & $-0,83$ \\
\hline 2004 & 4.756 .078 & 758.092 & 5.514 .170 & 5,23 \\
\hline 2005 & 5.166 .132 & 636.980 & 5.803 .112 & 5,23 \\
\hline 2006 & 4.859 .647 & 632.049 & 5.491 .696 & $-5,36$ \\
\hline 2007 & 5.082 .797 & 571.334 & 5.654 .131 & 2,95 \\
\hline 2008 & 5.540 .263 & 554.539 & 6.094 .802 & 7,79 \\
\hline 2009 & 5.765 .643 & 532.427 & 6.298 .070 & 3,33 \\
\hline 2010 & 6.125 .571 & 491.806 & 6.617 .377 & 5,06 \\
\hline 2011 & 5.912 .114 & 402.125 & 6.314 .239 & $-4,58$ \\
\hline 2012 & 5.751 .682 & 379.982 & 6.131 .664 & $-2,89$ \\
\hline 2013 & 5.899 .566 & 412.202 & 6.311 .762 & 2,93 \\
\hline 2014 & 5.881 .371 & 390.712 & 6.272 .083 & $-0,62$ \\
\hline 2015 & 5.962 .304 & 428.794 & 6.391 .098 & 1,89 \\
\hline 2016 & 5.991 .229 & 371.680 & 6.362 .909 & $-0,44$ \\
\hline 2017 & 6.365 .989 & 377.288 & 6.743 .277 & 5,97 \\
\hline 2018 & 6.728 .431 & 396.027 & 7.124 .458 & 5,65 \\
\hline 2019 & 6.681 .224 & 382.438 & 7.063 .662 & $-0,85$ \\
\hline $\begin{array}{l}\text { Ave- } \\
\text { rage }\end{array}$ & & & & 2,08 \\
\hline
\end{tabular}

From table 3 it can be seen that the number of the labor force in North Sumatra Province in 1990-2019 fluctuated between $3,948,729$ to $7,063,662$ people with an average growth of 2.08 . The increase in the labor force began in 2008 with 6,094,802 people, an increase of $7.79 \%$. The highest number of unemployed workers was in 2004 with 758,092 people.
The infrastructure system is the leading supporter of the functions of the social and economic system in people's daily lives. The infrastructure system can be defined as the basic facilities or structures, equipment, and installations built and needed to function the social system and the community's economic system (Grigg in Kodoatie, 2003).

Infrastructure in economics is a form of public capital formed from investments made by the government, which includes: roads, bridges, and sewer systems. At least there are some infrastructure benefits, including:

a. Improve connectivity between regions or between countries.

b. Increase the productivity of a region or country.

c. Increase efficiency in resource allocation.

d. Accelerate the equitable development of a region or country.

e. Encouraging new investment into the region or country.

The infrastructure system is the primary support for the functions of the social system and the economic system in people's daily lives. The infrastructure system can be defined as the basic facilities or structures, equipment, and installations built and needed to function the social system and the community's economic system (Grigg in Kodoatie, 2003). Efforts to improve the condition of infrastructure are recognized as an essential role in reducing income inequality and its long-term impact on GDP per capita. Infrastructure improvements have contributed to increasing productivity and are expected to support the economy in the long term.

Referring to the World Development Report (World Bank, 1994), infrastructure plays a vital role in increasing economic growth where higher economic growth is found in areas with adequate infrastructure availability. The identity of infrastructure development programs in several countries concludes that, in general, programs are targeted in the medium term, focusing on 
increasing basic needs and human connectivity, ranging from water, electricity, energy to transportation (roads, trains, ports, and airports). Weil (2009) states that the disparity in the availability of physical capital and human capital plays a role in explaining the differences in economic growth between countries.

Transportation is a means of connecting or connecting between production areas and markets, or it can be said to bring production areas and markets closer, or often said to bridge producers with consumers. The role of transportation is crucial, namely, connecting, bringing closer, and bridging between parties who need each other. (Adisasmita, 2011). Based on Law Number 38 of 2004 concerning Roads, what is meant by roads are land transportation infrastructure, which includes all parts of the road, including complementary buildings and equipment intended for traffic, which are on the ground surface, above the ground surface, below the ground surface, and water, as well as on the surface of the water, except for railroads, lorries, and cable roads.

Thus, economic infrastructure, in this case, the length of the road, is a physical capital stock that can be a prerequisite for other sectors to develop and create relationships between one another in improving the economy. Infrastructure, especially the length of roads, is critical in an area's economic development and community welfare because road infrastructure can facilitate the mobility of goods and people from one area to another. It will expedite and streamline the economic process. The length of roads in North Sumatra Province in 1990-2019 is shown in table 4.

Table 4. Road Length Based on Status and Conditions in North Sumatra Province 1990-2019

\begin{tabular}{|c|c|c|c|c|c|c|c|}
\hline \multirow[t]{2}{*}{ Years } & \multicolumn{3}{|l|}{ Province } & \multicolumn{3}{|c|}{ Regency/City } & \multirow[t]{2}{*}{ Total $(\mathrm{Km})$} \\
\hline & Good (Km) & Medium (Km) & Total (Km) & Good (Km) & Medium (Km) & Total $(\mathrm{Km})$ & \\
\hline 1990 & $1.475,77$ & 656,90 & 2132.67 & $2.384,59$ & $3.455,32$ & 5839.91 & 9651.03 \\
\hline 1991 & 489,80 & $1.078,14$ & 1567.94 & $2.344,15$ & $4.666,04$ & 7010.19 & 10150.84 \\
\hline 1992 & 489,80 & $1.078,14$ & 1567.94 & $2.344,15$ & $4.666,04$ & 7010.19 & 10150.84 \\
\hline 1993 & $1.055,03$ & 570,30 & 1625.33 & $1.853,77$ & $4.440,57$ & 6294.34 & 8462.45 \\
\hline 1994 & $1.109,59$ & 836,74 & 1946.33 & $3.858,05$ & $4.299,17$ & 8157.22 & 12016.1 \\
\hline 1995 & $1.063,84$ & $1.044,54$ & 2108.38 & $1.386,02$ & $3.476,11$ & 4862.13 & 8883.06 \\
\hline 1996 & $1.334,07$ & $1.353,46$ & 2687.53 & $1.758,50$ & $4.627,80$ & 6386.3 & 10980.94 \\
\hline 1997 & $1.334,07$ & $1.353,46$ & 2687.53 & $3.663,45$ & $4.516,02$ & 8179.47 & 13027.01 \\
\hline 1998 & $1.273,46$ & $1.305,43$ & 2578.89 & $3.663,45$ & $4.516,02$ & 8179.47 & 13088.4 \\
\hline 1999 & $1.035,19$ & $1.120,35$ & 2155.54 & $6.647,40$ & $4.312,10$ & 10959.5 & 13115.04 \\
\hline 2000 & $1.080,38$ & $1.279,79$ & 2360.17 & $4.178,73$ & $6.332,12$ & 10510.85 & 12871.02 \\
\hline 2001 & $1.113,50$ & $1.011,19$ & 2124.69 & $6.330,66$ & $7.295,09$ & 13625.75 & 15750.44 \\
\hline 2002 & $1.178,52$ & $1.103,38$ & 2281.9 & $7.721,68$ & $6.290,58$ & 14012.26 & 16294.16 \\
\hline 2003 & $1.841,68$ & 773,77 & 2615.45 & $7.772,75$ & $8.201,05$ & 15973.8 & 18589.25 \\
\hline 2004 & $1.729,91$ & 599,97 & $2.329,88$ & $8.131,14$ & $7.135,31$ & $15.266,46$ & $17.596,3$ \\
\hline 2005 & $1.783,29$ & 590,73 & $2.374,02$ & $9.040,91$ & $6.227,93$ & $15.268,84$ & 17.642 .8 \\
\hline 2006 & $1.796,01$ & 410,40 & $2.206,41$ & $10.227,14$ & $6.276,69$ & $16.503,84$ & $18.710,2$ \\
\hline 2007 & $1.875,28$ & 511,96 & $2.387,24$ & $9.339,17$ & $7.602,56$ & $16.941,74$ & 19.328 .9 \\
\hline 2008 & 825,72 & $1.182,99$ & 2.008 .71 & $9.589,11$ & $7.051,51$ & $16.640,62$ & $18.649,3$ \\
\hline 2009 & 963,43 & $1.065,46$ & $2.028,89$ & $9.589,11$ & $7.051,51$ & $16.640,62$ & $18.669,5$ \\
\hline 2010 & $1.124,36$ & $1.045,92$ & $2.170,28$ & $12.412,68$ & $4.966,27$ & $17.378,96$ & 19.549 \\
\hline 2011 & $1.395,71$ & 540,72 & $1.936,43$ & $12.801,79$ & $6.518,41$ & $19.320,21$ & $21.256,6$ \\
\hline 2012 & $1.272,40$ & 757,43 & $2.029,83$ & $13.879,01$ & $7.455,48$ & $21.334,49$ & $23.364,3$ \\
\hline 2013 & $1.325,23$ & 769,51 & $2.094,74$ & $12.310,98$ & $7.033,90$ & $19.344,88$ & $21.439,6$ \\
\hline 2014 & $1.190,19$ & $1.078,55$ & $2.268,74$ & $12.342,92$ & $6.993,91$ & $19.336,83$ & $21.605,5$ \\
\hline 2015 & $1.190,19$ & $1.190,19$ & $2,380.38$ & $12.342,92$ & $6.993,91$ & $19.336,83$ & $21.605,5$ \\
\hline 2016 & $1.397,82$ & $1.066,37$ & $2.464,19$ & $13.239,10$ & $4.850,62$ & $18.089,72$ & $20.553,9$ \\
\hline 2017 & $1.397,82$ & $1.066,37$ & $2.464,19$ & $12.610,32$ & $5.717,35$ & 18.327 .67 & $20.791,8$ \\
\hline 2018 & $1.026,77$ & $1.410,82$ & $2.437,59$ & $12.568,27$ & $5.862,37$ & $18.430,64$ & $20.868,2$ \\
\hline 2019 & $1.123,16$ & $1.347,24$ & $2.470,40$ & $12.568,27$ & $5.862,37$ & $18.430,64$ & $20.901,0$ \\
\hline
\end{tabular}

Based on the data in table 4 , the length of roads in good and moderate conditions in North Sumatra Province from
1990-2019 fluctuated. The length of roads in good and moderate condition in North Sumatra Province in 1990 reached 9,651.03 
$\mathrm{km}$, and in 2019 it reached 20,901.04 km. The increase of $11,250.01 \mathrm{~km}$ was because roads are vital facilities that will contribute to the smooth production and distribution of goods and services, which is expected to increase the region's economy.

\section{Previous Research Review}

Mutia et al. (2016) conducted a study on investment, labor, and government spending on economic growth in Indonesia. The study results show that (1) investment, labor, and government spending simultaneously affect economic growth in Indonesia; (2) investment, labor, and government spending partially affect economic growth in Indonesia.

Novitasari and Maryati (2013) examined the influence of infrastructure development on regional development in Indonesia. The results showed that the national road infrastructure most significantly affected the high level of GRDP income.

Nuritasari (2013) conducted a study on the effect of infrastructure, DI, and FI on the gross domestic product in Indonesia. The study results found that together infrastructure, DI, and FI had a positive and significant effect on the Gross Domestic Product in Indonesia. Moreover, partially DI and FI have no significant effect.

Tong et al. (2014) examined the relationship between transportation infrastructure, exports, and economic growth in the United States. The research, among others, found that the existence of roads affects economic growth indirectly through increasing the stock of nontransportation infrastructure capital and private capital.

Sitompul (2007) conducted a study on the effect of investment and labor on the GRDP of North Sumatra. The study results partially show that domestic investment, foreign direct investment, and the number of workers positively and significantly affect economic growth in North Sumatra.

Rustiono (2008) conducted a study on the Analysis of the Effect of Investment,
Labor, and Government Expenditure on Economic Growth in Central Java Province. The results showed that the analysis of the influence of FI, DI, Labor Force, and local government spending on the growth of Central Java Province showed a significant positive relationship. Meanwhile, the addition of the crisis dummy variable showed a significant negative effect on economic growth.

Raharjo (2006), through a study of the effect of government spending, private investment, and labor force on economic growth in Semarang City in 1982-2003. The analysis results show that the effect of private investment on economic growth in Semarang City shows positive and significant results. The labor force on economic growth in Semarang City shows positive but not significant results.

Candra (2012) researched the role of government spending, labor, and DI on economic growth in East Java Province in 2001-2010. The results of the study show that government spending, labor, and domestic investment affect economic growth. The three variables above have a positive and significant effect, except for the DI variable, which has a positive but not significant effect on economic growth.

Pradhan and Bahchi (2013) examined the effect of transportation infrastructure (roads and rails) on economic growth in India during the period 19702010. They use the Vector Error Correction Model (VECM), thus finding a two-way causality between road transportation and economic growth. This study indicates that the expansion of transport (both road and rail) and gross capital formation will lead to substantial growth of the Indian economy.

Putri (2014) examined the effect of investment, labor, capital expenditure, and infrastructure on the economic growth of Java Island in the period 2007-2011. The results showed that the variables of DI, FI, labor, capital expenditures, infrastructure, including asphalt roads, and electricity had a significant positive effect. In contrast, the non-asphalt roads had a significant but 
insignificant effect on Java's economic growth for 2007-2011. Simultaneously, the variables of DI, FI, labor, capital expenditure, infrastructure, which includes asphalt roads, non-asphalt roads, and electricity, have a significant effect on economic growth in Java for the period 2007-2011.

Wahyuni (2017) examines the influence of DI and FI and government spending on the GRDP of East Kalimantan Province. The results of this study indicate that DI has a positive and significant effect on the GRDP of East Kalimantan Province. FI has a negative and significant effect on GRDP, and government spending has a positive and insignificant effect on the GRDP of East Kalimantan Province.

\section{Framework}

Following the description of the background of the problem, literature review, and previous research, a conceptual research framework prepares as follows:

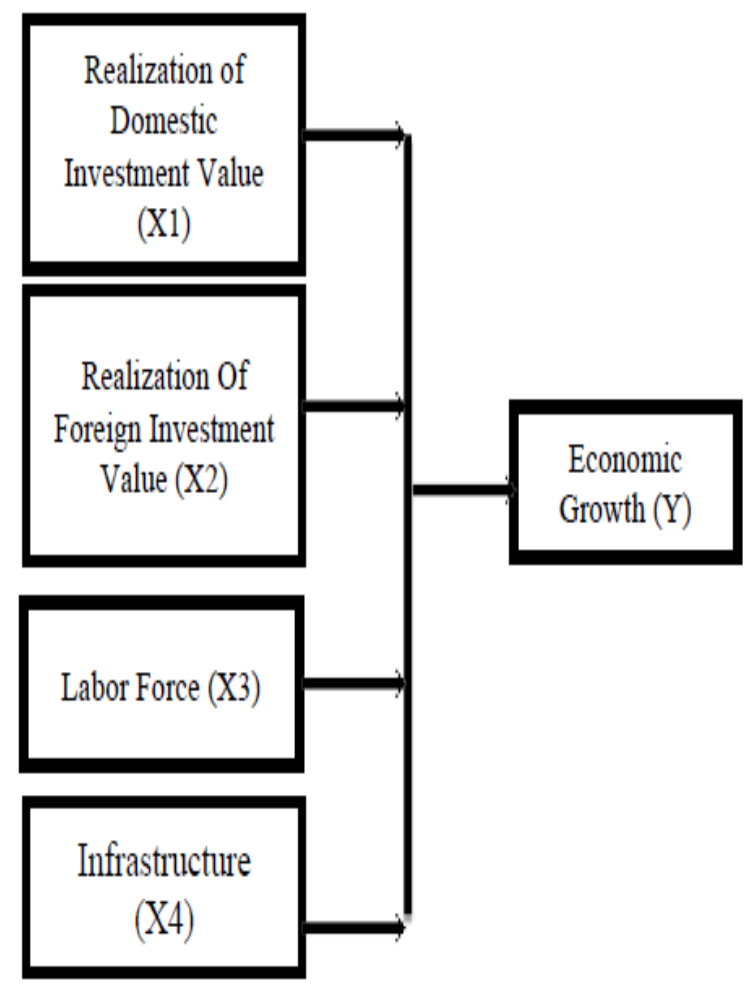

H1: The realization of the value of DI has a positive and significant effect on economic growth.
H2: Realization of FI value has a positive and significant effect on economic growth.

H3: The labor force has a positive and significant effect on economic growth.

H4: Road infrastructure has a positive and significant impact on economic growth.

H5: The realization of the value of DI, the realization of the value of FI, the labor force, and road infrastructure simultaneously have a positive and significant effect on economic growth.

\section{RESEARCH METHODS}

This study uses secondary annual time series data for the period 1990-2019 North Sumatra Province. The data used includes data on Gross Regional Domestic Product (GRDP), investment in the form of investment, namely the realization of the value of Domestic Investment (DI), the realization of the value of Foreign Investment (FI), Labor Force (LF), and Road Infrastructure (INF). Sources of data were obtained from the Central Statistics Agency (BPS).

The realization of the value of DI, the realization of the value of FI, the Labor Force, and Infrastructure on Economic Growth, the Ordinary Least Square (OLS) model of multiple linear regression quantitative analysis was used. To determine whether the estimation model used meets the Best Linear Unbiased Estimators (BLUE) or is close to the actual data so that it can be used as a prediction, for this, a classical assumption test is carried out with the help of Software Eviews 10. A two-tail t-test is used to determine the significance or significance of the influence of each independent variable on the dependent variable. The $\mathrm{F}$ test is used to determine whether the independent simultaneously significantly affect the dependent variable.

The coefficient of determination (R2) determines the independent's influence on the dependent variable. 
Taufik Akbar et.al. Analysis of the effect of investment, labor force and infrastructure on economic growth in North Sumatra Province.

\section{RESULT AND DISCUSSION Regression Analysis Results}

Table 5. Results of Multiple Regression Analysis Estimation Model

\begin{tabular}{|c|c|c|c|c|}
\hline Variable & Coefficient & Std. Error & t-Statistic & Prob. \\
\hline $\mathrm{C}$ & -19.57240 & 2.490014 & -7.860358 & 0.0000 \\
\hline LOG(XI) & 0.049962 & 0.015532 & 3.216676 & 0.0036 \\
\hline LOG(X2) & 0.010728 & 0.015847 & 0.676987 & 0.5046 \\
\hline LOG(X3) & 1.882208 & 0.205927 & 9.140152 & 0.0000 \\
\hline LOG(X4) & 0.220364 & 0.096106 & 2.292940 & 0.0305 \\
\hline R-squared & 0.974377 & \multirow{7}{*}{\multicolumn{2}{|c|}{$\begin{array}{l}\text { Mean dependent var } \\
\text { S.D. dependent var } \\
\text { Akaike info criterion } \\
\text { Schwarz criterion } \\
\text { Hannan-Quinn criter. } \\
\text { Durbin-Watson stat }\end{array}$}} & 12.44532 \\
\hline Adjusted R-squared & 0.970277 & & & 0.444454 \\
\hline S.E. of regression & 0.076625 & & & -2.148773 \\
\hline Sum squared resid & 0.146785 & & & -1.915240 \\
\hline Log likelihood & 37.23160 & & & -2.074064 \\
\hline F-statistic & 237.6709 & & & 1.452463 \\
\hline Prob(F-statistic) & 0.000000 & & & \\
\hline
\end{tabular}

From the results above, it is known that the probability for the DI variable is $0.0036<0.05$, the Labor Force is $0.0000<$ 0.05 , and the Infrastructure is $0.0305<0.05$, meaning that the DI, Labor Force, and Infrastructure variables have a significant effect. On Economic Growth in North Sumatra Province. Meanwhile, the FI variable has a probability of $0.5046>0.05$, which means that the variable has no significant effect on Economic Growth in North Sumatra Province.

\section{Classic Assumption Test Results Multicollinearity Test}

Table 6. Multicollinearity Test

\begin{tabular}{|c|c|c|c|}
\hline & Coefficient & Uncentered & Centered \\
\hline Variable & Variance & VIF & VIF \\
\hline C & 6.200170 & 31679.85 & NA \\
\hline LOG(X1) & 0.000241 & 228.6702 & 3.860051 \\
\hline LOG(X2) & 0.000251 & 190.7449 & 2.981799 \\
\hline LOG(X3) & 0.042406 & 51734.06 & 5.097230 \\
\hline LOG(X4) & 0.009236 & 4416.814 & 4.348098 \\
\hline \multicolumn{4}{|c}{ Source: Eviews 10 Software Results } \\
\hline
\end{tabular}

Based on the test results, the value of VIF centered for DI is 3.860051; FI = 2.981799; $\mathrm{LF}=5.097230 ; \mathrm{INF}=4.348098$. Because the VIF value of all independent variables is less than 10 , there is no multicollinearity in the four independent variables in this study.

\section{Autocorrelation Test}

Table 7. Autocorrelation Test Results

Breusch-Godfrey Serial Correlation LM Test:

\begin{tabular}{llll}
\hline \hline F-statistic & 0.931518 & Prob. F(2,23) & 0.4083 \\
Obs*R-squared & 2.247959 & Prob. Chi-Square(2) & 0.3250 \\
\hline \hline
\end{tabular}

The autocorrelation test was performed using the Breusch-Godfrey Serial Correlation LM Test. The analysis results show that the $\mathrm{F}$ (2.23) calculated probability value is 0.4083 , which means it is greater than $=0.05(5 \%)$. Thus, it is concluded that there is no autocorrelation.

\section{Normality test}

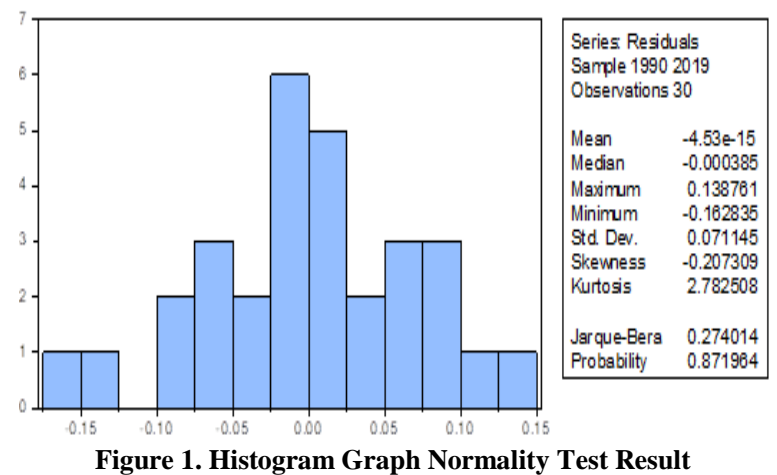

Histogram-Normal Test does normality test. The analysis results get a calculated probability value of JB (JarqueBera) of 0.871964 which means it is greater than the level of $=0.05(5 \%)$. Thus it is concluded that the residuals are normally distributed.

\section{Linearity Test}

\begin{tabular}{|c|c|c|c|}
\hline t-statistic & 0.518886 & 24 & 0.6086 \\
\hline F-statistic & 0.269243 & $(1,24)$ & 0.6086 \\
\hline Likelihood ratio & 0.334679 & 1 & 0.5629 \\
\hline
\end{tabular}

The linearity test was carried out using the Ramsey Reset Test. The analysis results get a probability value of $\mathrm{F}(1.24)$ 
calculated at 0.6086 , which means it is greater than the level of $=0.05(5 \%)$. Thus it is concluded that the regression model has met the assumption of linearity.

\section{Heteroscedasticity Test}

\section{Heteroskedasticity Test:Glejser}

\begin{tabular}{lll}
\hline \hline F-statsicic & 0.464970 Prob.F(4,25) & 0.7608 \\
Obs*R-squared & 2.077315 Prob.Chi-Square(4) & 0.7215 \\
Scaled explained SS & 1.921022 Prob.Chi.Square(4) & 0.7503 \\
\hline \hline
\end{tabular}

Source: Eviews 10 Software Results

The heteroscedasticity test was carried out using the Glejser Heteroskedasticity test. The results obtained are the probability value of $\mathrm{F}(4.25)$ of 0.7608 which means it is greater than the level of $=0.05(5 \%)$. Thus it is concluded that there is no heteroscedasticity.

From the results of the classical assumption test, namely the multicollinearity, autocorrelation, normality, linearity, and heteroscedasticity tests that have been carried out, it turns out that all assumptions are fulfilled. So that the estimation model can be used because it has met the requirements, namely Best, Linear, Unbiased Estimators (BLUE).

\section{Test of Conformity (Goodness of Fit)}

\begin{tabular}{crrrr}
\multicolumn{5}{c}{ Table 10. Results of Regression Analysis } \\
\hline \hline Variable & Coefficient & Std. Error & t-Statistic & Prob. \\
\hline \hline C & -19.57240 & 2.490014 & -7.860358 & 0.0000 \\
LOG(X1) & 0.049962 & 0.015532 & 3.216676 & 0.0036 \\
LOG(X2) & 0.010728 & 0.015847 & 0.676987 & 0.5046 \\
LOG(X3) & 1.882208 & 0.205927 & 9.140152 & 0.0000 \\
LOG(X4) & 0.220364 & 0.096106 & 2.292940 & 0.0305 \\
\hline \hline R-squared & 0.974377 & Mean dependent var & 12.44532 \\
Adjusted R-squared & 0.970277 & S.D. dependent var & 0.444454 \\
\hline \multicolumn{5}{c}{ Source: Eviews 10 Software Results } \\
\hline
\end{tabular}

\section{Partial Test (t-Test)}

Based on table 10 above, it can be concluded that DI, Labor Force, and Infrastructure have a positive and significant effect on Economic Growth in North Sumatra Province partially and FI has a positive and insignificant effect on Economic Growth in North Sumatra Province.

\section{Simultaneous Test (F Test)}

To determine the magnitude of the influence of the variables of DI, FI, LF, and INF simultaneously on economic growth, they are done by looking at the magnitude of the coefficient of determination obtained $\left(\mathrm{R}^{2}\right)$, the value of $\mathrm{R}^{2}=0.974377$ with a probability value of 0.000000 . When compared to the probability value obtained with $=0.05$, then $0.000000<0.05$, Ho is rejected, and $\mathrm{Ha}$ is accepted. Thus, DI, FI, LF, and INF simultaneously have a significant positive effect on the economic growth of North Sumatra Province. It means that $97.4377 \%$ of North Sumatra's economic growth is influenced by DI, FI, LF, and INF. Other variables influence the remaining $2.5623 \%$.

\section{CONCLUSION}

Based on the results of data analysis and research discussion, the following conclusions can be drawn:

1. The realization of the value of DI has a positive and significant impact on the economic growth of North Sumatra Province.

2. Realization of the value of FI has a positive and insignificant effect on the economic growth of North Sumatra Province.

3. The labor force has a positive and significant impact on the economic growth of North Sumatra Province.

4. Road infrastructure has a positive and significant impact on the economic growth of North Sumatra Province.

5. Realization of the value of DI, FI, labor force, and road infrastructure simultaneously has a positive and significant impact on the economic growth of North Sumatra Province.

\section{SUGGESTIONS}

1. To increase investment, local governments as policy makers should 
improve a conducive investment climate, make business licensing and tax management more leisurely and less time-consuming.

2. Road infrastructure is an essential part of encouraging the economic growth performance of a region. So the government should pay special attention to the development of road infrastructure so that its quality and quantity can benefit the people of North Sumatra province. Later, it will provide welfare for the community and increase the growth of the economy of North Sumatra province.

3. It is hoped that the labor force in the future can be increased with the hope that there will be policies in investment made by the government in all economic sectors so that more workers can be employed to impact economic growth.

\section{Acknowledgement: None}

\section{Conflict of Interest: None}

\section{Source of Funding: None}

\section{REFERENCES}

1. Adisasmita, Rahardjo. 2011. Manajemen Pemerintah Daerah. Yogyakarta: Penerbit Graha Ilmu.

2. Arsyad, Lincoln. 1999. Ekonomi Pembangunan. Edisi Keempat: Yogyakarta STIE YKPN.

3. Arsyad, Lincolin. 2010. Ekonomi Pembangunan, Edisi kelima. Yogakarta: UPP STIM YKPM.

4. Boediono, 1999. Teori Pertumbuhan Ekonomi. Yogakarta: Penerbit Fakultas Ekonomi Universitas Gajah Mada.

5. Badan Pusat Statistik Provinsi Sumatra Utara. Sumatra Utara Dalam Angka 19902019.

6. Candra E.W. 2012. Analisis Peranan Pengeluaran Pemerintah, Tenaga Kerja, dan Penanaman Modal Dalam Negeri (DI) terhadap Pertumbuhan Ekonomi Provinsi Jawa Barat Tahun 2001-2010. [jurnal ilmiah]. Fakultas Ekonomi dan Bisnis. Universitas Brawijaya, Malang.
7. Dornbusch, R. Dan Fisher, S., 2004. Makroekonomi Edisi Keempat, Alih Bahasa Mulyadi, JA, Jakarta: Penerbit Erlangga.

8. Effendi, Nur, dan Soemantri, Femmy M. 2003, "Foreign Direct Investment and Regional Economic Growth in Indonesia: A Panel Data Study," The 6th IRSA International Conference, Regional Development in The Era of Decentralization: Growth, Poverty, and Environment, Bandung.

9. Jufrida, F., Syechalad, M.N., \& Nasir, M. (2016) "Analisis Pengaruh Investasi Langsung (FI) dan Investasi dalam Negeri Terhadap Pertumbuhan Ekonomi Indonesia", Jurnal Perspektif ekonomi Darussalam, Volume 2, Nomor 1, ISSN 2502-6976.

10. Kodoatie, R.J, 2003. Manajamen dan Rekayasa Infrastruktur. Yogyakarta: Pustaka Pelajar

11. Makmun \& Lakhmad Yasin. 2003. Pengaruh Investasi dan Tenaga Kerja terhadap PDB Indonesia. Kajian ekonomi dan Keuangan Vol.7, No. 3, Sept.

12. Mutia, Sari., Nur Syechalad Mohd., Abd. Majid Sabri. 2016. Pengaruh Investasi, Tenaga Kerja, dan Pengeluaran Pemerintah terhadap Pertumbuhan Ekonomi di Indonesia. Jurnal Ekonomi dan Kebijakan Publik. Vol.3, No.2:109-115.

13. Nuritasari, Firdausi. 2013. "Pengaruh Infrastruktur, DI dan FI terhadap Produk Domestik Bruto di Indonesia", Economics Development Analysis Journal, Volume 2, Nomor 4, ISSN 2252-6889.

14. Ostry, Jonathan D., Atish R. Ghosh, Karl Habermeier, Marcos Chamon, Mahvash S. Qureshi, dan Dennis B,S Reinhardt. 2010. "Capital inflows: The role of controls." International Monetary Fund, 2010.

15. Pradhan, R.P., \& Bagchi, T.P. 2013. "Effect of Transportation Infrastructure on Economic Growth in India: the VECM approach," Research in Transportation Economics, 38(1): 139-148.

16. Peraturan Presiden Republik Indonesia Nomor 38 Tahun 2015 Tentang Kerjasama Pemerintah Dengan Badan Usaha Dalam Penyediaan Infrastruktur, Pasal 1 ayat 4.

17. Putri P.I. 2014. Pengaruh Investasi, Tenaga Kerja, Belanja Modal, Dan Infrastruktur Terhadap Pertumbuhan Ekonomi Pulau Jawa. [Jurnal] JEJAK 7 (2) (2014): 100-202. DOI: 10.15294/jejak.v7i1.3596. 
Taufik Akbar et.al. Analysis of the effect of investment, labor force and infrastructure on economic growth in North Sumatra Province.

18. Raharjo, Ardi. 2006. Pengaruh Pengeluaran Pemerintah, Investasi Swasta Dan Angkatan Kerja Terhadap Pertumbuhan Ekonomi Tahun 1982-2003 (Studi Kasus Di Kota Semarang). Masters Thesis, Program Pascasarjana Universitas Diponegoro.

19. Rustiono D. 2008. Analisis Pengaruh Investasi, Tenaga Kerja, dan Pengeluaran Pemerintah terhadap Pertumbuhan Ekonomi di Provinsi Jawa Tengah. [tesis]. Universitas Diponegoro, Semarang.

20. Salim H.S.,S.H., M.S. dan Budi Sutrisno, S.H., M.Hum. 2008. Hukum Investasi di Indonesia. Jakarta: Grafindo Persada.

21. Sitompul, Novita Linda. 2007. Analisis Pengaruh Investasi dan Tenaga Kerja terhadap PDRB SumatraUtara. [tesis]. Universitas SumatraUtara, Medan.

22. Sukirno, Sadono. 2000. Makroekonomi Modern. Jakarta: PT Raja Grafindo Persada

23. Todaro, Michael. P. 2000. Pembangunan Ekonomi di Dunia Ketiga. Edisi Ketujuh, Terjemahan Haris Munandar. Jakarta: Penerbit Erlangga.

24. Todaro, Michael P. \& Stephen C. Smith. 2004. Pembangunan Ekonomi di Dunia Ketiga, Edisi Kedelapan. Jakarta: Erlangga.

25. Tong, T., Edward Yu dan Roland K.Robert 2014. Dynamics of Transport Infrastructure, Exports and Economic Growth in the United States, Journal of the Transportation
Research Forum, Vol. 53, No.1 (Spring 2014), pp. 65-81.

26. Tran, H.T.T.,\& Hoang, H.T. (2019) “ $A n$ Investigation into the Impacts of FI, Domestic Investment Capital, Human Resources and Trained Workers on Economic Growth in Vietnam," International Econometric Conference of Vietnam-Springer.

27. Wahyuni, Sri. 2017. Pengaruh Penanaman Modal dalam Negeri dan Penanaman Modal Asing serta Pengeluaran Pemerintah terhadap Produk Domestik Regional Bruto Provinsi Kalimantan Timur. DOI:10.29264/JIEM.V2I1.1013

28. Weil, David. 2009. Economic Growth. (Second Edition), New York: Pearson Addison Wesley.

29. World Bank. 1994. World Bank Development Report 1994: Infrastructure for Development. New York: Oxford University Press.

How to cite this article: Akbar T, Tarmizi, Syafii. Analysis of the effect of investment, labor force and infrastructure on economic growth in North Sumatra Province. International Journal of Research and Review. 2021; 8(10): 184-195. DOI: https://doi.org/10. 52403/ijrr.20211023 